\title{
Synthetic Study of Matrine-Type Alkaloids: Stereoselective Construction of the AB Rings of the Quinolizidine Skeleton
}

\section{$\operatorname{AUTHOR}(S):$}

Tsukano, Chihiro; Oimura, Atsuko; Enkhtaivan, Iderbat; Takemoto, Yoshiji

\section{CITATION:}

Tsukano, Chihiro ...[et al]. Synthetic Study of Matrine-Type Alkaloids: Stereoselective Construction of the AB Rings of the Quinolizidine Skeleton. Synlett 2014, 25(5): 653-656

\section{ISSUE DATE:}

2014-03-05

\section{URL:}

http://hdl.handle.net/2433/199887

\section{RIGHT:}

(c) Georg Thieme Verlag Stuttgart · New York; This is not the published version. Please cite only the published version.; この論文は出版社版で ありません。引用の際には出版社版をご確認ご利用ください。 


\title{
Synthetic Study of Matrine-type Alkaloids: Stereoselective Construction of the $A B$ rings of the Quinolizidine Skeleton
}

\author{
Chihiro Tsukano, Atsuko Oimura, Iderbat Enkhtaivan, Yoshiji Takemoto* \\ Graduate School of Pharmaceutical Sciences, Kyoto University, Yoshida, Sakyo-ku, Kyoto, 606-8501, Japan \\ Fax:+81(75)7534532; E-mail: Takemoto@pharm.kyoto-u.ac.jp \\ Received: The date will be inserted once the manuscript is accepted.
}

Abstract: A new method has been developed for the stereoselective construction of the $\mathrm{AB}$ rings of the quinolizidine skeleton of matrine-type alkaloids with a cis-cis stereochemistry. The key features of this method involve: (i) the construction of the quinolizidine by the reduction of an acylpyridinium cation; and (ii) the late stage introduction of methoxypyridine by sequential Stille coupling and diastereoselective hydrogenation reactions.

Keywords: Quinolizidines, stereoselective synthesis, alkaloids, matrine, pyridines

Matrine is representative of the alkaloids derived from Sophora flavescens Ait., and has been used for many years as a traditional Chinese medicine (KuShen). ${ }^{1}$ The structure of matrine is characterized by a tetracyclic core consisting of two quinolizidines and four contiguous stereogenic centers (Figure 1). ${ }^{2}$ To date, over 30 matrine-type alkaloids have been reported in the literature, and these compounds usually only differ from each other in terms of their oxidation level and relative stereochemistry. ${ }^{3}$ Alkaloids belonging to this structural class also exhibit a variety of biological properties, including antitumor $^{4 a, e}$, anti-viral ${ }^{4 b, c}$, and anti-inflammatory ${ }^{4 \mathrm{~d}}$ activities. Because of their interesting and diverse biological activities, these compounds have attracted considerable attention from medicinal chemists.

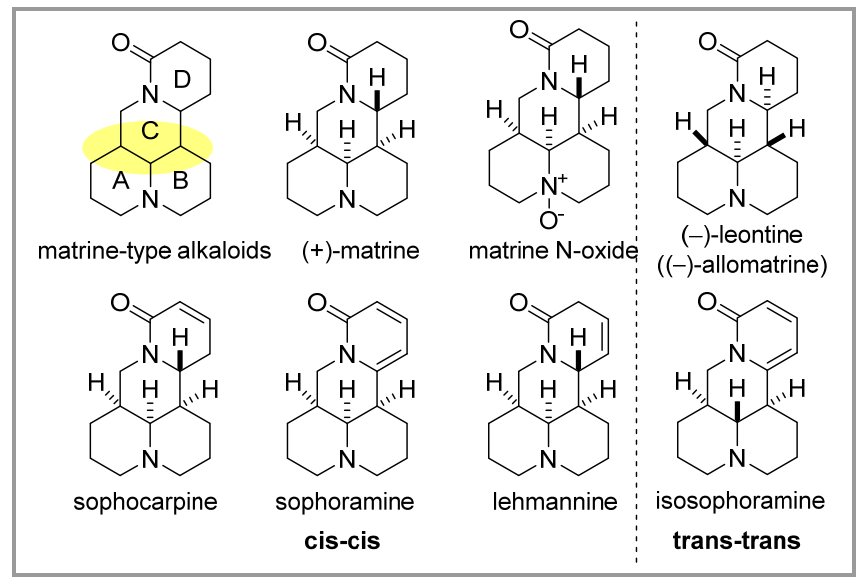

Figure 1 Matrine and related quinolizidine alkaloids.

Although there are many congeners in this structural class, only four racemic total syntheses and three semi-syntheses have been reported to date, including those of matrine $e^{6-8,9 a}$, leontine ${ }^{6 a}$, sophoramine ${ }^{9 b}$ and isosophoramine. $^{9 \mathrm{c}, 10}$ These syntheses revealed that the stereoselective construction of the tetracyclic core of these compounds represents a significant synthetic challenge. Brown et al. ${ }^{11}$ recently reported the synthesis of $(+)$-allomatrine, where the tetracyclic core was elegantly constructed in a diastereoselective manner using an imino-aldol reaction and $\mathrm{N}$ acyliminium cyclization. Methods for the stereoselective synthesis of tetracyclic cores with a cis-cis configuration, however, such as those found in sophoramine and matrine, remain scarce. We recently reported a procedure for the synthesis of quinolizidines by the reduction of acylpyridinium cations under mild conditions. ${ }^{5}$ It was envisaged that this method could be used as a powerful tool for the concise synthesis of quinolizidine alkaloids, because the resulting products could be readily derivatized. With this in mind, we became interested in investigating the application of our method to the stereoselective synthesis of the $\mathrm{AB}$ rings of matrine type alkaloids with cis-cis stereochemistry.

Retrosynthetically, alcohol $\mathbf{1}$ was set as a suitable synthetic target, because it was envisaged that this compound would provide comprehensive access to matrine and several related alkaloids via the cyclization of the $\mathrm{C}$ ring and the adjustment of the oxidation levels (Scheme 1). The cis-cis stereochemistry of 1 could be successfully installed by the hydrogenation of compound $\mathbf{2}$ or $\mathbf{5}$. Compound $\mathbf{2}$

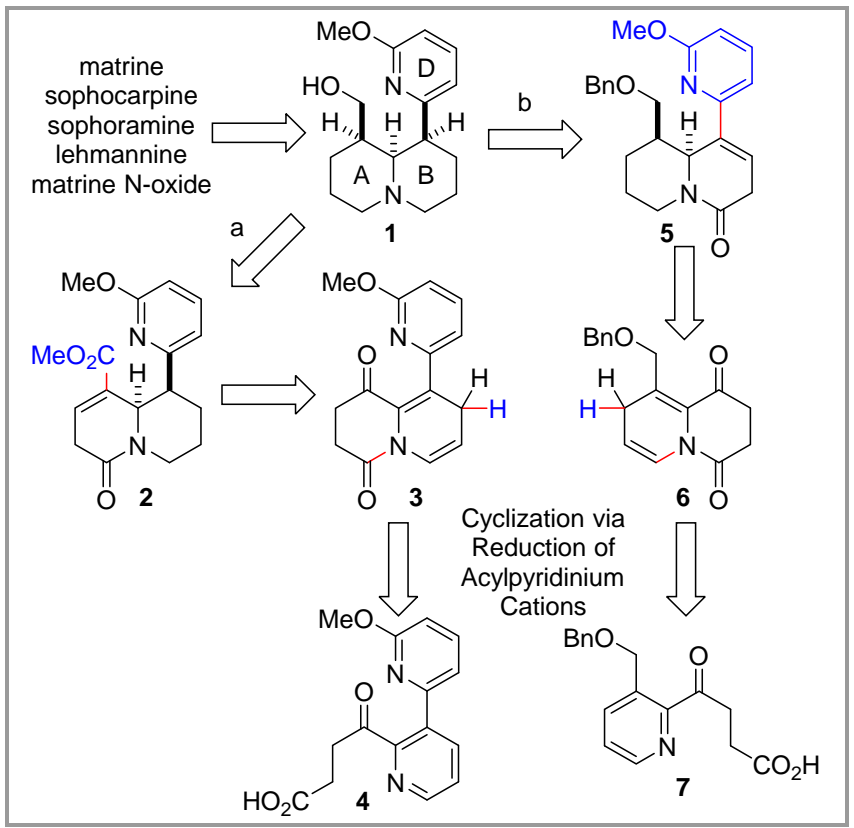

Scheme 1 Retrosynthetic analysis of matrine type alkaloids. 
could be accessed via the introduction of a $\mathrm{C} 1$ unit to the quinolizidine core of compound 3 , which could be constructed via the reduction of the acylpyridinium cation derived from carboxylic acid 4 (route a). Alternatively, the addition of a pyridyl moiety to compound 6, which could be derived from 7, could also be used to provide access alcohol $\mathbf{1}$ (route b). Herein, we report the development of a stereoselective synthesis of the key cis-cis intermediate $\mathbf{1}$ based on our reductive cyclization strategy by examining both possibilities.

To begin, we examined route a, which required the challenging selective reduction of one of two pyridines. The synthesis of the cyclization precursor 4 started with the Stille coupling of 2-iodopicolinate methyl ester $\mathbf{8}^{12}$ and pyridylstannane $\mathbf{9}^{13}$ using catalytic amounts of $\mathrm{Pd}\left(\mathrm{PPh}_{3}\right)_{4}$ and $\mathrm{CuI}$ (Scheme 2). $\mathrm{CuI}$ was essential for the production of bipyridine 10. ${ }^{14}$ Compound 10 was converted to carboxylic acid $\mathbf{4}$ by the Horner-Wadsworth-Emmons reaction of $\mathbf{1 1}$ with ethyl glyoxylate, followed by sequential hydrogenation and hydrolysis reactions, which gave the cyclization precursor 4 in 50\% yield from the coupling product $10 .{ }^{15}$ The quinolizidine skeleton was constructed by the reduction of the acylpyridinium cation intermediate, which was produced by the activation of one of the two pyridine rings of 4 . Treatment of 4 with Ghosez's reagent followed by Hantzsch ester gave the desired product 3 in $36 \%$ yield. This low yield was attributed to the unfavorable nucleophilic attack of the nitrogen of the other pyridine on the in situ generated acid chloride. Hydrogenation of the cyclized product 3 proceeded stereoselectively to give the desired compound $\mathbf{1 2}$ as a

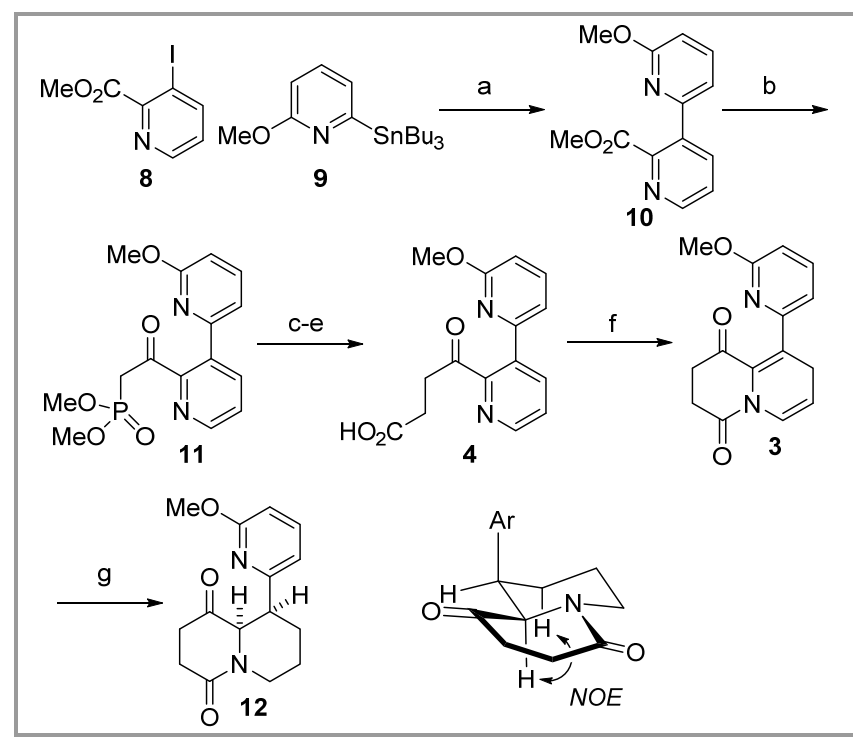

Scheme 2 Synthesis of bipyridine $\mathbf{4}$ and it's cyclization. (a) $\mathrm{Pd}\left(\mathrm{PPh}_{3}\right)_{4}, \mathrm{CuI}, \mathrm{DMF}, 110{ }^{\circ} \mathrm{C}, 74 \%$; (b) $n \mathrm{BuLi}, \mathrm{MeP}(\mathrm{O})(\mathrm{OMe})_{2}$, THF, $-78{ }^{\circ} \mathrm{C}$; (c) $t \mathrm{BuOK}, \mathrm{EtO}_{2} \mathrm{CCHO}$, DME, $-20{ }^{\circ} \mathrm{C}, 57 \%(2$ steps); (d) $\mathrm{H}_{2}, \mathrm{Pd} / \mathrm{C}$, AcOEt; (e) LiOH, THF- $\mathrm{H}_{2} \mathrm{O}, 88 \%$ (2 steps); (f) Ghosez's reagent, MS $4 \AA$ then Hantzsch ester, $\mathrm{ClCH}_{2} \mathrm{CH}_{2} \mathrm{Cl}$, $36 \%$; (g) $\mathrm{H}_{2}, \mathrm{Pd} / \mathrm{C}, \mathrm{EtOH}, 70 \%$. single isomer. The newly generated stereochemistry was confirmed by NOE experiments. Whilst ketone 12 was accessed in stereoselective manner, the quinolizidine ring formation resulted in a low yield and we decided to then focus our efforts on the other route for accessing the cis-cis intermediate $\mathbf{1}$.

The second route started from 2-bromo-3hydroxymethylpyridine $(\mathbf{1 3})^{16}$, which was converted to the corresponding benzyl ether 14 using standard techniques (Scheme 3). Subsequent treatment of $\mathbf{1 4}$ with $n$-butyl lithium followed by the addition of succinic anhydride $\mathbf{1 5}$ gave carboxylic acid 7, albeit in low yield $(45 \%)$. To improve the yield and reproducibility of this step, compound $\mathbf{1 4}$ was first converted to the 2-TMS-pyridine species, which was treated with succinic anhydride $\mathbf{1 5}$ to give carboxylic acid 7 in $65 \%$ yield over two steps. ${ }^{15,17}$ Compound 7 was then successfully converted to compound 6 by treatment with Ghosez's reagent followed by Hantzsch ester. ${ }^{18}$ Compound $\mathbf{6}$ was found to be unstable, and was immediately hydrogenated over $\mathrm{Pd} / \mathrm{C}$ to give ketone 16, whose stereochemistry was confirmed by NOE experiments and the coupling constants in its ${ }^{1} \mathrm{H}$ NMR, as shown in Figure 2. The second route performed more effectively than the first route in terms of the number of steps required and the yield of the key cyclization step.

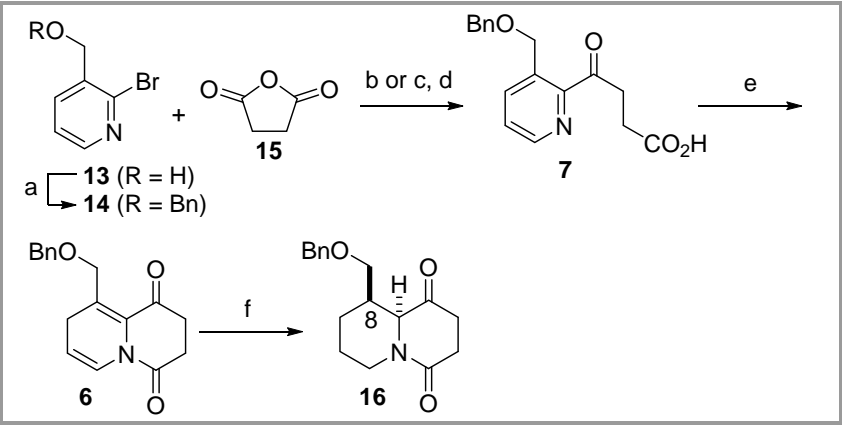

Scheme 3 Synthesis of quinolizidine 16. (a) $\mathrm{BnBr}, \mathrm{NaH}, \mathrm{DMF}$, $68 \%$; (b) $n \mathrm{BuLi}$ then succinic anhydride $15, \mathrm{Et}_{2} \mathrm{O},-78{ }^{\circ} \mathrm{C}$ to RT, $45 \%$; (c) $n \mathrm{BuLi}$, TMSCl, $\mathrm{Et}_{2} \mathrm{O},-78{ }^{\circ} \mathrm{C}$ to RT; (d) $15, \mathrm{ClCH}_{2} \mathrm{CH}_{2} \mathrm{Cl}$, $100{ }^{\circ} \mathrm{C}, 65 \%$ (two steps); (e) Ghosez's reagent, MS $4 \AA$ then Hantzsch ester, $\mathrm{ClCH}_{2} \mathrm{CH}_{2} \mathrm{Cl}, 0^{\circ} \mathrm{C}$ to RT, $61 \%$; (f) $\mathrm{H}_{2}, \mathrm{Pd} / \mathrm{C}$, $\mathrm{EtOH}, 53 \%$
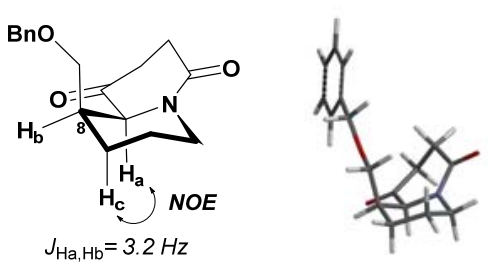

Figure $2{ }^{1} \mathrm{H}$ NMR coupling constant and NOESY experiments of compound 16 (left) and a stable conformation calculated by Spartan at the B3LYP/6-31+G(d) level of theory (DFT) (right).

We then proceeded to investigate the stereoselective introduction of the pyridyl moiety into compound $\mathbf{1 6 .}$ Preliminary studies revealed that the structurally 
related ketone 12 was readily enolized rather than attacked by nucleophiles such as $\mathrm{TMSCH}_{2} \mathrm{Li}$ and $\mathrm{Ph}_{3} \mathrm{P}=\mathrm{CH}_{2}{ }^{19}$ The treatment of compound $\mathbf{1 6}$ with NaHMDS and Comins' reagent gave enol triflate 17 together with a significant amount of its regioisomer 18 in a combined yield of $61 \%(\mathbf{1 7 : 1 8}=1.3: 1)$ (Scheme 4). A variety of different bases (i.e., LDA, LiTMP, TrLi, KHMDS, NaHMDS, LiHMDS, Et ${ }_{3} \mathrm{~N}$ ) and triflating reagents (i.e., $\mathrm{Tf}_{2} \mathrm{O}, \mathrm{Tf}_{2} \mathrm{NPh}$, and Comins' reagent ${ }^{20}$ ) were evaluated for this transformation, but none of these combinations led to an improvement in the low regioselectivity. Pleasingly, it was possible to separate these two compounds by silica gel column chromatography, and this allowed for sufficient quantities of the enol triflate 17 to be obtained for the subsequent Stille coupling. Following an extensive investigation of the conditions required for the coupling of $\mathbf{1 7}$ with $\mathbf{9}$ using several copper salts such as $\mathrm{CuTC}^{21}, \mathrm{CuBr} \bullet \mathrm{SMe}_{2}$, and $\mathrm{CuDPP}^{22}$, it was found that the reaction proceeded smoothly in the presence of catalytic $\mathrm{Pd}\left(\mathrm{PPh}_{3}\right)_{4}$ with CuDPP (copper(I) diphenylphosphinate) and $\mathrm{LiCl}$ in $\mathrm{THF}$ at $50{ }^{\circ} \mathrm{C}$ to give the coupling product 5 in good yield. Hydrogenation of 5 gave compound 19 as a single isomer, because the $\alpha$ face was shielded by the hydroxymethyl group (Figure 3, left). The newly generated stereochemistry was confirmed by NOE experiments (Figure 3, right). Finally, reduction with $\mathrm{LiAlH}_{4}$ gave the common intermediate 1 with the required cis-cis stereochemistry. ${ }^{23}$

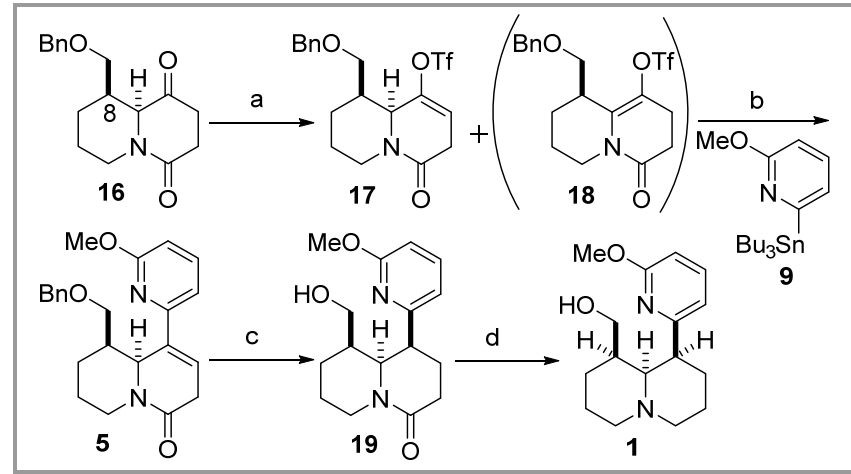

Scheme 4 Synthesis of common intermediate 1. (a) NaHMDS, Comins' reagent, THF, -78 to $0{ }^{\circ} \mathrm{C}, 61 \%,(\mathbf{1 7}: 18=1.3: 1)$; (b) $\mathbf{9}$, $\mathrm{Pd}\left(\mathrm{PPh}_{3}\right)_{4}, \mathrm{CuDPP}, \mathrm{LiCl}$, THF, $50{ }^{\circ} \mathrm{C}, 67 \%$; (c) $\mathrm{Pd} / \mathrm{C}, \mathrm{H}_{2}$ (5 atm), EtOH, $70{ }^{\circ} \mathrm{C}, 65 \%$; (d) $\mathrm{LiAlH}_{4}$, THF, $50{ }^{\circ} \mathrm{C}, 80 \%$.

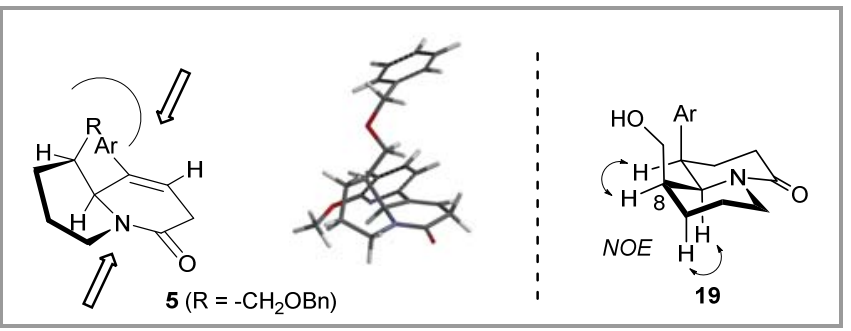

Figure 3 Regioselectivity of hydrogenation of compound 5 (left), a stable conformation calculated by Spartan at the B3LYP/6$31+\mathrm{G}(\mathrm{d})$ level of theory (DFT) (middle), NOESY experiments of compound 19 (right).
In summary, we have developed a method for the concise synthesis of quinolizidine $\mathbf{1}$ in a stereoselective manner. The key features of this method include: (i) the construction of the quinolizidine ring by the reduction of an acylpyridinium cation; and (ii) the late stage introduction of a pyridyl group by sequential Stille coupling and hydrogenation reactions. This synthetic strategy represents a reasonable technique for the stereoselective construction of quinolizidine rings with cis-cis stereochemistry. The synthesis of matrinetype alkaloids such as sophoramine, sophocarpine and matrine from quinolizidine $\mathbf{1}$ via the construction of the $\mathrm{C}$ ring and subsequent adjustment of the oxidation levels is currently underway in our laboratory.

Supporting Information for this article is available online at http://www.thieme-connect.com/ejournals/ toc/synlett.

\section{Acknowledgment}

This work was supported by a Grant-in-Aid for Young Scientists (B) (C. T.) from the Japan Society for the Promotion of Science.

\section{References}

(1) Nagai, N,; Kondo, H. Yakugaku Zasshi 1903, 260.993.

(2) (a) Tsuda, K.; Saeki, S.; Imura, S.-I.; Okuda, S.; Sato, Y.; Mishima, H. J. Org. Chem. 1956, 21, 1481. (b) Ochiai, E.; Okuda, S.; Minato, H. Yakugaku Zasshi 1952, 72, 781.

(3) (a) Micheal, J. P. Nat. Prod. Rep. 2008, 25, 139. (b) K. A. Aslanov, Y. K. Kushmuradov, S. Sadykov, In The Alkaloids, Vol. 31; Brossi, A., Ed.; Academic Press: 1987, 117, and references therein.

(4) For recent examples of biological studies, see (a) Wang, L.; You, Y.; Wang, S.; Liu, X.; Liu, B.; Wang, J.; Lin, X.; Chen, M.; Liang,; Yang, H. G. Bioorg. Med. Chem. Lett., 2012, 22, 4100. (b) Yang, Y.; Xiu, J.; Zhang, X.; Zhang, L.; Yan, K.; Qin, C.; Liu, J. Molecules, 2012, 17, 10370. (c) Gao, L.-M.; Han, Y.-X.; Wang, Y.-P.; Li, Y.H.; Shan, Y.-Q.; Li, X.; Peng, Z.-G.; Bi, C.-W.; Zhang, T.; Du, N.-N.; Jiang, J.-D.; Song, D.-Q. J. Med. Chem. 2011, 54, 869. (d) Hu, H.; Wang, S.; Zhang, C.; Wang, L.; Ding, L.; Zhang, J.; Wu, Q. Bioorg. Med. Chem. Lett. 2010, 20, 7537. (e) Ma, L.; Wen, S.; Zhan, Y.; He, Y.; Liu, X.; Jiang, J. Planta Med. 2008, 74, 245.

(5) Tsukano, C.; Oimura, A.; Enkhtaivan, I; Takemoto, Y. Org. Lett. 2012, 14, 1902.

(6) (a) Mandell, L.; Singh, K. P.; Gresham, J. T.; Freeman, W. J. J. Am. Chem. Soc. 1965, 87, 5234. (b) Mandell, L.; Piper, J. U.; Singh, K. P. J. Org. Chem. 1963, 28, 3440. (c) Mandell, L.; Singh, K. P. J. Am. Chem. Soc. 1961, 83, 1766.

(7) Chen, J.; Browne, L. J.; Gonnela, N. C. J. Chem. Soc., Chem. Commun., 1986, 905.

(8) Boiteau, L.; Boivin, J.; Liard, A.; Quiclet-Sire, B.; Zard, S. Z. Angew. Chem. Int. Ed. 1998, 37, 1128.

(9) (a) Okuda, S.; Kamata, H.; Tsuda, K.; Murakoshi, I. Chem. \& Ind. (London), 1962, 1326. (b) Okuda, S.; Yoshimoto, M.; Tsuda, K. Chem. Pharm. Bull. 1966, 14, 275. (c) Okuda, S.; Kamata, H.; Tsuda, K. Chem. Pharm. Bull. 1963, 11, 1349. 
(10) Wenkert, E.; Chauncy, B.; Dave, K. G.; Jeffcoat, A. R.; Schell, F. M.; Schenk, H. P. J. Am. Chem. Soc. 1973, 95, 8427.

(11) Watkin, S. V.; Camp, N. P.; Brown, R. C. D. Org. Lett. 2013, 15, 4596.

(12) Carson, M. W.; Giese, M. W.; Coghlan, M. J. Org. Lett. 2008, 10, 2701.

(13) Honda, T.; Takahashi, R.; Namiki, H. J. Org. Chem. 2005, 70, 499.

(14) Liebeskind, L. S.; Fengl, R. W. J. Org. Chem. 1990, 55, 5359 .

(15) Tsukano, C.; Zhao, L.; Takemoto, Y.; Hirama, M. Eur. J. Org. Chem. 2010, 4198.

(16) (a) Ashimori, A.; Ono, T.; Uchida, T.; Ohtaki, Y.; Fukaya, C.; Watanabe, M.; Yokoyama, K. Chem. Pharm. Bull., 1990, 38, 2446. (b) Srinivasan, J. M.; Burks, H. E.; Smith, C. R.; Visvanathan, R.; Johnston, J. N. Synthesis, 2005, 330.

(17) Pinkerton, F. H.; Thames, S. F. J. Organomet. Chem. 1970, 24, 623 .

(18) Synthesis of 1,4-Dihydropyridine 6: To a solution of carboxylic acid $7(2.20 \mathrm{~g}, 7.34 \mathrm{mmol})$ and MS4A (ca. 5 g) in $\mathrm{CH}_{2} \mathrm{Cl}_{2}(50 \mathrm{~mL})$ at $0{ }^{\circ} \mathrm{C}$ was added Ghosez's reagent $(1.00 \mathrm{ml}, 7.41 \mathrm{mmol})$. The mixture was stirred at $0{ }^{\circ} \mathrm{C}$ for $30 \mathrm{~min}$, then Hantzsch ester $(5.58 \mathrm{~g}, 22.0$ $\mathrm{mmol}$ ) was added to the reaction mixture. After stirring at room temperature for $2 \mathrm{~h}$, the mixture was filtered and concentrated under reduced pressure. The residue was purified by column chromatography on silica gel (2-3\% ether/toluene) to afford dihydropyridine 6 (1.28 g, $4.52 \mathrm{mmol}, 61 \%$ ) as a solid; IR (ATR) 2979, 2721, $1689,1235,1089,893 \mathrm{~cm}^{-1} ;{ }^{1} \mathrm{H}$ NMR $(500 \mathrm{MHz}$ $\left.\mathrm{CDCl}_{3}\right) \delta 7.35-7.25(\mathrm{~m}, 5 \mathrm{H}), 7.08(\mathrm{dt}, \mathrm{J}=8.0,1.7 \mathrm{~Hz}$, $1 \mathrm{H}), 5.13(\mathrm{dt}, \mathrm{J}=8.3,3.5 \mathrm{~Hz}, 1 \mathrm{H}), 4.60-4.57(\mathrm{~m}, 2 \mathrm{H})$, 4.49 (s, 2H), 3.19-3.17 (m, 2H), 2.74 (ddd, $\mathrm{J}=8.3,6.0$, $1.5 \mathrm{~Hz}, 2 \mathrm{H}), 2.67(\mathrm{ddd}, \mathrm{J}=8.3,6.0,1.5 \mathrm{~Hz}, 2 \mathrm{H}) ;{ }^{13} \mathrm{C}$ NMR (126 MHz, CDCl3) $\delta 192.3,165.3,138.1,132.8$, $128.9,128.5,127.8,127.7,122.7,108.1,73.0,69.7$, 35.9, 29.7, 25.9; MS (FAB) $\mathrm{m} / \mathrm{z} 284\left[(\mathrm{M}+\mathrm{H})^{+}\right]$; HRMS (FAB) calcd for $\mathrm{C}_{17} \mathrm{H}_{18} \mathrm{NO}_{3}\left[(\mathrm{M}+\mathrm{H})^{+}\right] 284.1287$, found 284.1296 .

(19) We also found that the related ketone, which did not have a substituent on the quinolizidine ring, enolized under the conditions of the Grignard and Wittig reactions. See ref. 5.

(20) Comins, D. L.; Dehghani, A. Tetrahedron Lett. 1992, 33, 6299.

(21) Allred, G. D.; Liebeskind, L. S. J. Am. Chem. Soc. 1996, 118,2748 .

(22) Wittenberg, R.; Srogl, J.; Egi, M.; Liebeskind, L. S. Org. Lett. 2003, 5, 3033.

(23) Synthesis of quinolizidine 1: To a solution of alcohol 19 (11.3 $\mathrm{mg}, 0.0390 \mathrm{mmol})$ in THF $(1 \mathrm{~mL})$ was added dropwise a solution of $\mathrm{LiAlH}_{4}(2.2 \mathrm{mg}, 0.058 \mathrm{mmol}, 1.5$ eq) in anhydrate THF $(0.6 \mathrm{~mL})$ at $0{ }^{\circ} \mathrm{C}$ under argon. The resulting mixture was stirred at $50^{\circ} \mathrm{C}$ for $30 \mathrm{~min}$. After careful hydrolysis with $3 \mathrm{M}$ aq. $\mathrm{NaOH}(1 \mathrm{~mL})$, EtOAc (1 $\mathrm{mL}$ ) was added and the organic layer was separated. The aqueous layer was extracted with EtOAc $(1 \times 2 \mathrm{~mL})$. The combined organic layers were dried over $\mathrm{Na}_{2} \mathrm{SO}_{4}$, filtered, and concentrated. The crude residue was purified by column chromatography $\left(\mathrm{CHCl}_{3}-\mathrm{MeOH}\right.$, 20:1) to give alcohol $1(10.8 \mathrm{mg}, 0.035 \mathrm{mmol}, 80 \%)$ as an oil. IR (ATR) 3356, 2928, 2857, 2754, 2683, 1578, $1466 \mathrm{~cm}^{-1} ;{ }^{1} \mathrm{H}$ NMR $\left(500 \mathrm{MHz}, \mathrm{CDCl}_{3}\right) \delta 7.47(\mathrm{dd}, J=$ 8.0, 7.4 Hz, 1H), $7.00(\mathrm{~d}, J=7.4 \mathrm{~Hz}, 1 \mathrm{H}), 6.57(\mathrm{~d}, J=$ $8.0 \mathrm{~Hz}, 1 \mathrm{H}), 3.91(\mathrm{~s}, 3 \mathrm{H}), 3.65-3.54(\mathrm{~m}, 2 \mathrm{H}), 3.46(\mathrm{dd}, J$ $=11.2,3.0 \mathrm{~Hz}, 1 \mathrm{H}), 3.20(\mathrm{dd}, J=8.5,6.3,4.0 \mathrm{~Hz}, 1 \mathrm{H})$, 2.98 (br d, $J=11.7 \mathrm{~Hz}, 1 \mathrm{H}), 2.87-2.83(\mathrm{~m}, 2 \mathrm{H}), 2.30$ - $2.14(\mathrm{~m}, 3 \mathrm{H}), 2.10-2.02(\mathrm{~m}, 2 \mathrm{H}), 1.86-1.81(\mathrm{~m}, 2 \mathrm{H})$, $1.59-1.43(\mathrm{~m}, 3 \mathrm{H}) ;{ }^{13} \mathrm{C}$ NMR $\left(126 \mathrm{MHz}, \mathrm{CDCl}_{3}\right) \delta$ 163.1, 160.8, 138.3, 116.2, 107.7, 67.2, 64.9, 57.7, 53.3, $45.2,37.9,31.9,30.7,29.6,21.7,21.6 ; \mathrm{MS}$ (FAB) m/z $277.2\left[(\mathrm{M}+\mathrm{H})^{+}\right]$; HRMS (FAB) calcd for $\mathrm{C}_{16} \mathrm{H}_{25} \mathrm{~N}_{2} \mathrm{O}_{2}$ $\left[(\mathrm{M}+\mathrm{H})^{+}\right] ; 277.1911$, found 277.1913 . 
Synthetic Study of Matrine-type Alkaloids: Stereoselective Construction of the AB rings of the Quinolizidine Skeleton

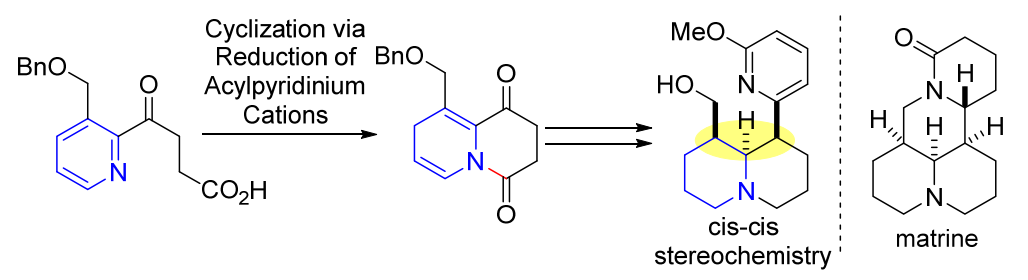

